\title{
Distribution and Occurrence of Vairimorpha plodiae (Opisthokonta: Microspora) in the Indian Meal Moth, Plodia interpunctella (Lepidoptera: Pyralidae) Populations: An Extensive Field Study
}

\author{
Tuğba SAĞLAM ${ }^{1}$, Mustafa YAMAN ${ }^{1}$, Ömer ERTÜRK² \\ ${ }^{1}$ Department of Biology, Faculty of Arts and Science, Bolu Abant İzzet Baysal University, Turkey \\ ${ }^{2}$ Department of Molecular Biology and Genetics, Faculty of Arts and Science, Ordu University, Turkey
}

\begin{abstract}
The Indian meal moth, Plodia interpunctella (Lepidoptera: Pyralidae) is one of the most important stored product pests. Fumigation plays a significant role in the management of insect pests in stored-products. However, the use of fumigants is problematic because of their effects on the environment and high costs. Entomopathogenic organisms are environmentally friendly control agents and suppress pest populations under natural conditions. In this study, distribution and occurrence of a microsporidian pathogen, Vairimorpha plodiae (Opisthokonta: Microspora) in the populations of P. interpunctella from 12 localities representing Turkey between 2019 and 2020 are presented for the first time by confirming its effectiveness on natural populations. The presence of the microsporidian pathogen was found in 11 of $12(91.7 \%)$ populations. In total, 863 of 3,044 samples were infected by the pathogen. Infection mean was $28.4 \%$ for all populations. Our results showed that $V$. plodiae infection reached to a considerably high prevalence $(88.77 \%)$ in $P$. interpunctella populations and varied from 5.1 to $88.7 \%$ between the populations. In addition, microsporidia infections have been identified throughout Turkey. We found that $V$. plodiae can infect all life stages of $P$. interpunctella. Totally, $623(28.5 \%)$ of 2187 larvae, 14 (37.8\%) of 37 pupae, $226(27 \%)$ of 820 adults were found to be infected by the pathogen. There were considerable differences between the dead and living larvae. The microsporidian infection was found in $26(11.6 \%)$ of 225 living larvae, whereas it was found in $595(30.5 \%)$ of 1,952 dead larvae. These results confirm that the microsporidia pathogen has a high spreading potential in P. interpunctella populations and can be a natural biological suppression factor on pest populations.
\end{abstract}

Keywords: Plodia interpunctella, Vairimorpha plodiae, biological control, stored product pest, entomopathogen.

\section{INTRODUCTION}

Although there are several beneficial roles of insects in research (as a model species) (Takov et al. 2020), medical and agricultural fields (Demirözer et al.

Address for correspondence: Mustafa Yaman, Department of Biology, Faculty of Arts and Science, Bolu Abant İzzet Baysal University, 14030, Bolu, Turkey; e-mail: muyaman@hotmail.com
2020), several insects cause damage to plants growing and stored products in agriculture (Rees 2004; Kuyulu and Genç 2020; İnal and Kandemir 2020). The Indian meal moth, Plodia interpunctella (Lepidoptera: Pyralidae) is a major pest of stored products (McGaughey 1985). Damage to stored products by $P$. interpunctella is a major problem for food manufacturers, retailers, and consumers (Campos and Phillips 2010). Fumigation plays a significant role in the management of insect pests in the stored-products. However, the use of 
fumigants is problematic because of their effects on the environment and high costs. Due to the harmful effects of chemicals on humans as well as non-target organisms (Arikan and Turan 2020), different alternative control methods are sought today. Entomopathogenic organisms are environmentally friendly control agents and suppress pest populations under natural conditions. Therefore, the most reliable and promising agents against stored product pests are ecologically safely control agents (Adarkwah and Schöller 2012; Freitas et al. 2020), especially natural pathogenic microorganisms (Dales 1994).

The natural enemies of $P$. interpunctella have been investigated in more detail. There are numerous papers on natural enemies and pathogens of $P$. interpunctella, such as viruses, bacteria, protists, fungi, nematodes, and parasitoids (Adarkwah and Schöller 2012; Batta 2016; Cowan 1986; Knell et al. 1996; Malone 1984a; Mbata and Shapiro-Ilan 2005; Yaman et al. 2016). Microsporidia are important regulatory entomopathogenic microorganisms on insect populations due to their common and high infection in insects (Yaman et al. 2019, Yaman 2020). There are some records regarding the presence of microsporidian pathogens in P. interpunctella (Kellen and Lindegren 1971; Kellen and Lindegren 1973; Malone 1984a, 1984b; Yaman et al. 2016) and several studies on its natural enemies (Adarkwah and Schöller 2012; Batta 2016; Cowan 1986; Dales 1974; Knell et al. 1996, Malone 1984a; Mbata and Shapiro-Ilan 2005; Yaman et al. 2016). However, none of them includes the distribution and occurrence of the enemies in the natural populations of $P$. interpunctella in an extensive field study. Understanding the forces affecting the insect population provides valuable insight into disease dynamics and helps to manage insect populations. In this study, distribution and occurrence of Vairimorpha plodiae (Opisthokonta: Microspora) in the populations of $P$. interpunctella from 12 localities representing all Turkey between the years 2019-2020 is given for the first time by confirming its effectiveness on natural populations.

\section{MATERIALS AND METHODS}

\section{Insect Samples}

A total of 3044 P. interpunctella samples (820 adults, 1952 dead and 235 living larvae, and 37 pupae) were collected from different stored products such as nut, walnut, peanut, chestnut, dry fig, apricot, and flour in warehouses, shops, and houses in 12 provinces, widely dispersed geographically in Turkey during the two years (2019-2020). Since the sampling localities have different climatic and geographical characteristics, the biological periods of the pest may occur at different times. For this reason, sampling dates are given in detail in Table 1.

\section{Microscopic Examination}

Firstly, the samples were taken for macroscopic examination. After macroscopic examination, living and dead samples were separated individually. $P$. interpunctella larva, pupa, and adult samples were dissected in Ringer's solution and then prepared wet smears including host fat body, malpighian tubules, gut epithelium, and hemolymph were examined for the presence of the microsporidian infection under a light microscope at a magnification of 400-1000X. When infection was found, the slides were air-dried and fixed with methanol, then stained with freshly prepared $5 \%$ solution of Giemsa stain. They were then washed in running tap water, air-dried, and examined under a microscope (Yaman et al. 2019).

\section{RESULTS AND DISCUSSION}

During the study, $3044 P$. interpunctella samples including larvae, pupae, and adults were dissected and searched for the microsporidian pathogen, Vairimorpha plodiae in the 12 localities of Turkey between the years 2019-2020. Microsporidium infection was confirmed by observation of the oval spores studied in detail by Yaman et al. (2016) as evidence of $V$. plodiae infection. The presence of the microsporidian pathogen was found in $11(91.7 \%)$ of 12 populations (Figure 1$)$. No infection was observed only in one population. Although sampling was done on different dates from different localities, no correlation was observed between sampling dates and infection rates. In total, 863 of the 3044 samples were infected by the pathogen. The infection mean was $28.4 \%$ for all populations. The results in this study showed that the $V$. plodiae infection reached to considerable high prevalence $(88.77 \%)$ in $P$. interpunctella populations and varied from 5.1 to $88.7 \%$ between the populations (Table 2). The enzootic prevalence of microsporidian infection varies from occasional or continuous presence at low levels to wide levels that increase greatly (Solter et al. 2012). There are some reasons for that such as specific pathogen-host interactions, high host density, and the population dynamics of the host. On the other hand, larval population density and size of $P$. interpunctella may vary depending upon food resources and characteristics of the parental population. Furthermore, Gage (1995) mentioned that this species has a very cosmopolitan diet and populations vary considerably in nature from a few individuals to 


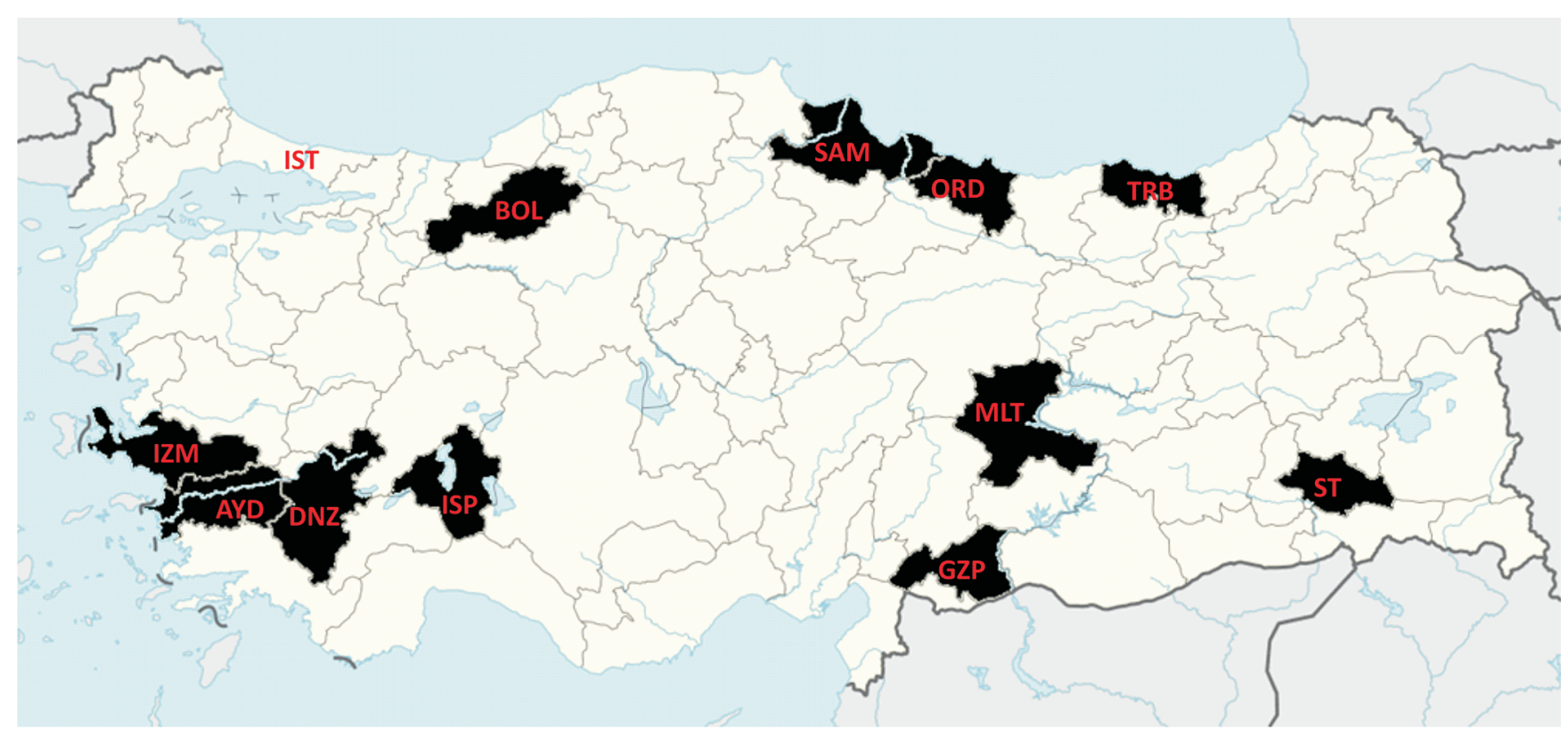

Fig. 1. The microsporidian pathogen, Vairimorpha plodiae infections in Plodia interpunctella populations in Turkey. Infected populations (note that the pathogen naturally disperses in all populations). (AYD: Aydın, BOL: Bolu, DNZ: Denizli, GZP: Gaziantep, ISP: Isparta, IST: İstanbul, İZM: İzmir, MLT: Malatya, ORD: Ordu, SAM: Samsun, ST: Siirt, TRB: Trabzon)

high densities developed over many generations. In addition, Sait et al. (1994) observed the dynamics of granulosis virus pathogen itself were highly unstable and there was little evidence for linked host-pathogen fluctuations. On the other hand, theoretical studies suggest that disease may play an important role in the population dynamics of insects (Sait et al. 1994). The variability in infection rates observed among populations in this study supports that the rate of infection in a population may depend on $P$. interpunctella population density and dynamics. The results of this study are also important as they support understanding how $V$. plodiae can help to regulate $P$. interpunctella populations under natural conditions and evaluate the potential of the microsporidian pathogen as a pest control agent.

During the study, we also determined the infection rates among the different life stages (larva, pupa, and adult) in different populations. It is showed that $V$. plodiae infects all life stages of $P$. interpunctella. Totally, $623(28.5 \%)$ of 2187 larvae, $14(37.8 \%)$ of 37 pupae, $226(27 \%)$ of 820 adults were found to be infected by the pathogen (Table 3). The highest infection rate was observed in pupae $(37.8 \%)$. When compared with the adult, larval and pupal infections, the pupal infection was higher than larval and adult infections and also total mean infection (Table 3). There is a statistically significant difference in the infection levels of pupae/ living larvae and adults/living larvae of $P$. interpunctella (Pearson Chi-square, P: $0,000<0.05$ ). Lower microsporidial virulence may allow the host to complete its life cycle and ensures transmission of the pathogen to the next host generation via the egg or embryo (Solter et al., 2012). The prevalence of the microsporidian pathogen observed in all life stages of $P$. interpunctella confirms that the infection with the lower virulence of $V$. plodiae ensures transmission of the pathogen through all life stages and to the next host generation.

We also focused on the infection rates between dead and living larvae. We found considerable differences between the dead and the living larvae. The microsporidian infection was found in $26(11.6 \%)$ of 225 living larvae, while it was found in 595 (30.5\%) of 1952 dead larvae (Table 3). The dead larval infection was about three times more than the living larval infection. There is a statistically significant difference in the infection levels of living and dead larvae of $P$. interpunctella (Pearson Chi-square, P: $0,000<0.05$ ). Microscopical observations also supported the differences between larval infections. The spore density of the microsporidian pathogen was higher in dead larvae. The higher infection levels observed in dead larvae show that the microsporidian pathogen is a main factor of the larval death. 
Table 1. Sampling localities and dates for Plodia interpunctella populations

\begin{tabular}{|c|c|}
\hline $\begin{array}{l}\text { Sampling } \\
\text { populations }\end{array}$ & Sampling Date \\
\hline AYD & $12.06 .2019,02.07 .2019,22.07 .2019,18.06 .2020,30.06 .2020$ \\
\hline BOL & $\begin{array}{l}\text { 22.05.2019, 28.06.2019, 08.07.2019, 20.08.2019, 05.09.2019, } \\
\text { 05.09.2019, 12.09.2019, 20.01.2020, 18.02.2020, 11.03.2020, } \\
\text { 23.03.2020, 30.04.2020, 01.06.2020, 13.07.2020 }\end{array}$ \\
\hline DNZ & $01.06 .2019,28.06 .2019$ \\
\hline GZP & 05.07.2019, 05.08.2019, 11.09.2019, 22.07.2020, 27.07.2020, \\
\hline ISP & $02.05 .2019,13.07 .2019,06.08 .2020,31.08 .2020$ \\
\hline IST & $20.12 .2019,16.03 .2020,02.04 .2020$ \\
\hline IZM & 12.06 .2019 \\
\hline MLT & 13.06.2019, 21.06.2019, 12.09.2019, 16.07.2020, 20.08.2020 \\
\hline ORD & $18.06 .2019,21.06 .2020$ \\
\hline SAM & $10.06 .2019,10.07 .2020$ \\
\hline SRT & 28.06 .2019 \\
\hline TRB & $15.06 .2019,10.07 .2020$ \\
\hline
\end{tabular}

Table 2. Occurrence of $V$. plodiae in P.interpunctella populations

\begin{tabular}{llll}
\hline Populations & $\begin{array}{l}\text { Number } \\
\text { of examined }\end{array}$ & $\begin{array}{l}\text { Number of } \\
\text { infected }\end{array}$ & Infection rate (\%) \\
\hline AYD & 101 & 58 & 57.42 \\
BOL & 1114 & 389 & 35 \\
DNZ & 9 & 3 & 33.33 \\
GZP & 411 & 21 & 5.11 \\
ISP & 100 & 72 & 72 \\
IST & 121 & 0 & 0 \\
IZM & 45 & 15 & 33.33 \\
MLT & 499 & 48 & 9.61 \\
ORD & 192 & 15 & 7.81 \\
SAM & 187 & 166 & 88.77 \\
SRT & 145 & 69 & 47.58 \\
TRB & 120 & 7 & 5.8 \\
Total & 3044 & 863 & 28.4 \\
\hline
\end{tabular}

On the other hand, the microsporidian pathogen, V. plodiae was found in $11(91.7 \%)$ of 12 investigated localities, a considerable large area representing all Turkey (Figure 1). As shown in Figure 1, V. plodiae is very common and widespread in the populations of $P$. interpunctella. Such a widespread infection is a desirable property for a biological control agent (Pereira et al.
2002). The results confirmed that $V$. plodiae infections are desirable and significant natural suppressor factor in P. interpunctella populations.

There have been several methods of pest control for stored-product pests, but their effectiveness is limited, and alternatives are needed. However, there are few studies on natural entomopathogenic organisms suppressing $P$. interpunctella populations. Until now, microsporidian pathogens, Nosema plodiae (Kellen and Lindegren 1971, 1973), Vairimorpha plodia (Malone 1984a, Malone 1984b, Yaman et al. 2016), neogregarine pathogen, Mattesia dispora (Wendell and Dicke 1964), gregarine pathogen, Leidyana sp. (Suzaki et al. 2006), bacterial pathogen, Bacillus thuringiensis (Kantack 1959, Nwanze et al. 1975, Kinsinger and McGaughey 1976, McGaughey 1978), baculoviruses, nucleopolyhedrovirus (Hunter et al. 1973) and granulovirus (Wilson and Consigli 1985) and fungal pathogens, Beauveria bassiana (Adane et al. 1996), Metarhizim anisoplia, Paecilomyces farinosus and Lecanicillium (Verticillium) lecanii (Būda and Pečiulytè 2008), and nematodes, Steinernema feltiae (Oğuzoğlu and Özer 2007), Steinernama riobrave (Ramos-Rodríguez et al. 2007), Heterorhabditis indica, Heterorhabditis marelatus and Heterorhabditis megidis (Mbata and ShapiroIlan 2005) have been studied as potential control agents against $P$. interpunctella. However, there is no study on the distribution, occurrence and potential of microbial pathogen in P. interpunctella under natural conditions. In this study, distribution and occurrence of Vairimorpha plodiae (Opisthokonta: Microspora) in the populations of $P$. interpunctella from 12 localities representing all Turkey between the years 2019-2020 is given in an extensive field study for the first time by confirming its effectiveness on natural populations.

Microsporidian effects range from nearly benign to relatively virulent, with infections causing the death of the host. Microsporidia utilize insect tissues for their reproductive energy and development. They invade tissues to cause chronic infections in insects, and their effects are manifested in reduced fertility and pupal weight, decreased fertility, and shortened lifespan (Solter et al. 2012). The genus Vairimorpha in the phylum Microspora includes the most potential microbial insecticide candidate species. V. necatrix is a virulent and promising pathogen with high mortality in lepidopteran pests (Maddox et al. 1981; Down et al. 2004). Therefore, the results of this study on Vairimorpha plodiae, an important pathogen of the lepidopteran pest $P$. interpunctella are of great importance to put forth 
Table 3. Occurrence of $V$. plodiae in the different life stages of $P$. interpunctella

\begin{tabular}{llll}
\hline Life stage & $\begin{array}{l}\text { Number of } \\
\text { examined sample }\end{array}$ & $\begin{array}{l}\text { Number } \\
\text { of infected sample }\end{array}$ & $\begin{array}{l}\text { Infection } \\
\text { rate (\%) }\end{array}$ \\
\hline Larva (Living) & 235 & 28 & 12 \\
Larva (Dead) & 1952 & 595 & 30.5 \\
Pupa & 37 & 14 & 37.8 \\
Adult & 820 & 226 & 27.6 \\
Total & 3044 & 863 & 28.3 \\
\hline
\end{tabular}

that the microsporidian pathogen, $V$. plodiae is very common and widespread and naturally occurs in $P$. interpunctella populations with the high infections in all life stages larvae, pupae, and adults.

Acknowledgment. The study was financially supported by a research project by the Scientific and Technological Research Council of Turkey (Project no: 1180980).

\section{REFERENCES}

Adane K., Moore D., Archer S. A. (1996) Preliminary studies on the use of Beauveria bassiana to control Sitophilus zeamais (Coleoptera: Curculionidae) in the laboratory. J. Stored Prod. Res. 32: $105-113$

Adarkwah C., Schöller M. (2012) Biological control of Plodia interpunctella (Lepidoptera: Pyralidae) by single and double releases of two larval parasitoids in bulk stored wheat. J. Stored Prod. Res. 51: 1-5

Arıkan T. K., Turan S. L. (2020) Organochlorine pesticide residues in feathers of four bird species from western part of Turkey. Turk J. Zool. 44: 401-407

Batta Y. A. (2016) Recent advances in formulation and application of entomopathogenic fungi for biocontrol of stored grain insects. Biocontrol Sci. Technol. 26: 1171-1183

Boğ E. Ş., Ertürk Ö., Yaman M. (2020) Pathogenicity of aerobic bacteria isolated from honey bees (Apis mellifera) in Ordu province. Turk J. Vet. Anim. Sci. 44: 714-719

Būda V., Pečiulyte D. (2008) Pathogenicity of four fungal species to Indian meal moth Plodia interpunctella (Hübner) (Lepidoptera: Pyralidae). Ekologija 54: 265-270

Gage M.J.G. (1995) Continuous variation in reproductive strategy as an adaptive response to population density in the moth Plodia interpunctella. Proc. R. Soc. Lond. B 261: 25-30

Campos M., Phillips T. W. (2010) Contact toxicity of insecticidesfor attract-and-kill applications against adult Plodia interpunctella (Hübner) (Lepidoptera: Pyralidae). Pest Manag. Sci. 66: 752-61

Cowan D. K., Vail P. V., Kok-Yokomi M. L., Schreiber F. C. (1986) Formulation of granulosis virüs of Plodia interpunctella (Hübner) (Lepidoptera: Pyralidae): efficacy, persistence and influence on oviposition and larval survival. J. Econ. Entomol. 79: 1085-1090
Dales M. J. (1994) Controlling insect pests of stored products using insect growth regulators and insecticides of microbial origin, NRI Bulletin 64, University of Greenwich. Natural Resorces Institute, ISBN: 0-85954-386-2

Down R. E., Bell H. A., Kirkbride A. E., Edwards J. P. (2004) The pathogenicity of Vairimorpha necatrix (Microspora: Microsporidia) against the tomato moth, Lacanobia oleracea (Lepidoptera: Noctuidae) and its potential use for the control of Lepidopteran glass house pests. Pest Manag. Sci. 60: 755-764

Demirözer O., Pekbey G., Hayat R., Herdoğan A., Acanski J., Milicic M., Uzun A. (2020) First contribution on distribution, abundance, and species richness of blowfly species (Diptera) of Isparta Province with five new records for the Turkish fauna. Turk J. Zool. 44: 69-79

Freitas A. C. O., Gigliolli A. A. S., Caleffe R. T. C., Conte H. (2020) Insecticidal effect of diatomaceous earth and dolomite powder against Corn weevil Sitophilus zeamais Motschulsky, 1855 (Coleoptera: Curculionidae. Turk J. Zool. 44: 490-497

Hunter D. K., Hoffmann D. F., Collier S. J. (1973) Cross-Infection of a Nuclear Polyhedrosis Virus of the Almond Moth to the Indian Meal Moth. Journal of Invertebrate Pathology 22: 186192

İnal B., Kandemir İ. (2020) DNA barcoding of black cherry aphid Myzus cerasi (Fabricus, 1775) (Hemiptera: Aphididae) populations collected from Prunus avium and Prunus cerasus. Turk J. Zool. 44: 146-155

Kantack B. E., (1959) Laboratory Studies with Bacillus thuringiensis Berliner and Its Possible Use for Control of Plodia interpunctella (Hbn.). J. Econ. Entomol. 52: 1226-1227

Kellen W. R., Lindegren J. E. (1971) Modes of transmission of Nosema plodiae Kellen and Lindegren, a pathogen of Plodia interpunctella (Hübner). J. Stored Prod. Res. 7: 31-34

Kellen W. R., Lindegren J. E. (1973) Transovarian transmission of Nosema plodiae in the Indian-meal moth, Plodia interpunctella. J. Invertebr. Pathol. 21: 248-254

Kinsinger R. A., McGaughey W. H., (1976) Stability of Bacillus thuringiensis and a Granulosis Virus of Plodia interpunctella on Stored Wheat. J. Econ. Entomol. 69: 149-154

Knell R. J., Begon M. J., Thompson D. (1996) Transmission dynamics of Bacillus thuringiensis infecting Plodia interpunctel$l a$ : a test of the mass action assumption with an insect pathogen. The Royal Society 263: 1366

Kuyulu A., Genç H. (2020) Genetic diversity of codling moth Cydia pomonella L. (Lepidoptera: Tortricidae) populations in Turkey. Turk J. Zool. 44: 462-471

Maddox J. V., Brooks W. M., Fuxa J. R. (1981) Vairimorpha necatrix, a pathogen of agri- cultural pests: potential for pest control. In: Burges H. D. (ed.) Microbial Control of Pests and Plant Diseases, Academic Press. London, pp. 587-594

McGaughey W. H., (1978) Response of Plodia interpunctella and Ephestia cautella Larvae to Spores and Parasporal Crystals of Bacillus thuringiensis. J. Econ. Entomol. 71: 687-688

McGaughey W. H. (1985) Insect resistance to the biological insecticide Bacillus thuringiensis. Science 229: 193-195

Malone L. A. (1984a) Factors controlling in vitro hatching of Vairimorpha plodiae (Microspora) spores and their infectivity to Plodia interpunctella, Heliothis virescens and Pieris brassicae. J. Invertebr. Pathol. 44: 192-197

Malone L. A. (1984b). A comparison of the development of Vairimorpha plodiae and Vairimorpha necatrix in the Indian meal moth, Plodia interpunctella. J. Invertebr. Pathol. 43: 140-149

Mbata G. N., Shapiro-Ilan D. I. (2005) Laboratory Evaluation of Virulence of Heterorhabditid Nematodes to Plodia interpunc- 
tella Hübner (Lepidoptera: Pyralidae). Entomological Society of America 34: 676-682

Nwanze K. Z., Partida G. J., McGaughey W. H. (1975) Susceptibility of Cadra cautella and Plodia interpunctella to Bacillus thuringiensis on Wheat. J. Econ. Entomol. 68: 751-752

Oğuzoğlu I., Özer N. (2007) Bioassays of Entomopathogen Nematode Steinernema feltiae All Type (Rhabditida: Steinernematidae) and Heterorhabditis bacteriophora Tur- H2 (Rhabditida: Heterorhabditidae). Hacettepe Journal of Biology and Chemistry 35: 1

Ramos-Rodríguez O. F., Campbell J. B., Ramaswamy S. (2007) Efficacy of the entomopathogenic nematode Steinernema riobrave against the stored-product insect pests Tribolium castaneum and Plodia interpunctella. Biological Control 40: 15-21

Pereira R. M., Williams D. V., Becnel J. J., Oi H. D. (2002) Yellow-head disease caused by a newly discovered Mattesia sp. in populations of the red imported fire ant, Solenopsis invicta. J. Invertebr. Pathol. 81: 45-48

Rees D. (2004) Insects of Stored Products. Collingwood VIC, Csiro Publishing: Australia

Takov D. I., Ostoich P. V., Tchorbanov A. I., Pilarska D. K. (2020) Order Diptera as a model in the studies of insect immunity: a review. Turk J. Zool. 44: 481-489

Sait S. M., Begon M., Thompson D. J. (1994) Long-term population dynamics of the Indian meal moth Plodia interpunctella and its granulosis virus. Journal of Animal Ecology 63: 861-870
Solter L. F., Becnel J. J., Oi D. H. (2012) Microsporidian entomopathogens. In Insect Pathology, Elsevier Inc., pp. 221-263. DOI: 10.1016/B978-0-12-384984-7.00007-5

Suzaki T., Uwo M. F., Noda H., Takeda M. (2006) A new gregarine parasite of Plodia interpunctella (Insecta: Lepidoptera). Japanese Journal of Protozoology 39: 130-131

Wendell E. B., Dicke R. J. (1964) Detection by Ultraviolet Light of Stored-Product Insects Infected with Mattesia dispora. J. Econ. Entomol. 57: 818-819

Wilson M. E., Consigli R. A. (1985) Characterization of a protein kinase activity associated with purified capsids of the granulosis virus infecting Plodia interpunctella. Virology 143: 516-525

Yaman M., Güngör F. P., Güner B. G., Radek R., Linde A. (2016) First report and spore ultrastructure of Vairimorpha plodiae (Opisthokonta: Microspora) from Plodia interpunctella (Lepidoptera: Pyralidae) in Turkey. Acta Parasitologica 61: 228-231

Yaman M., Alg1 G., Radek R. (2019) Morphological, ultrastructural and molecular identification of a new microsporidian pathogen isolated from Crepidodera aurata (Coleoptera, Chrysomelidae). Turk J Zool. 43: 407-415

Yaman M. (2020) Transmission of Microsporidium sp. between different generations of Crepidopdera aurata (Coleoptera: Chrysomelidae). Turk J. Zool. 44: 248-253

Received on $30^{\text {th }}$ December, 2020; revised on $23^{\text {rd }}$ June, 2021; accepted on $24^{\text {th }}$ June, 2021 